JAN WOLEŃSKI (Kraków)

\title{
O państwie prawa: uwagi filozofa
}

Art. 2 Konstytucji RP z 1997 r. powiada: „Rzeczpospolita jest demokratycznym państwem prawnym, urzeczywistniającym zasady sprawiedliwości społecznej”. Pominę kwestię sprawiedliwości społecznej i jej urzeczywistniania, notorycznie niejasna, aczkolwiek uchodząca, gdy już zdecyduje się czym jest, za jedną z tzw. prawdziwych sprawiedliwości. W tym kontekście warto pamiętać o przenikliwej uwadze Mrożka (nieco parafrazuję i upraszczam oryginalne sformułowanie), że prawdziwa sprawiedliwość jest wtedy, gdy nie ma zwykłej. Państwa prawnego, a raczej terminu ,państwo prawne” nie da się jednak załatwić tak prosto. Na pierwszy rzut oka wygląda on na thumaczenie niemieckiego słowa Rechtsstaat. Nie jest jednak, ponieważ zwrot „,państwo prawa”, a nie „państwo prawne”, jest poprawnym tłumaczeniem rzeczownika Rechtsstaat (niekiedy będę posługiwał się terminem niemieckim ze względów stylistycznych). Oczywiście można się umówić, że państwo prawne jest tym samym, co państwo prawa ${ }^{1}$. Takie kwestie jednak nie powinny być rozstrzygane konwencjonalnie. Przy okazji warto zauważyć, że rozważany termin niemiecki do niedawna w ogóle nie miał odpowiednika w języku angielskim i języku francuskim. Anglicy powiadali o rule of law, czyli rządach prawa (praworządności), a Francuzi od czasu Deklaracji Praw Człowieka z 1787 r. o principe de légalité (zasada praworządności). Dopiero całkiem ostatnio pojawily się terminy légal state i état du droit $\mathrm{w}$ związku $\mathrm{z}$ coraz większą popularnością koncepcji państwa prawa w Unii Europejskiej. Ten drugi literalnie znaczy to samo co „państwo prawa”, natomiast pierwszy jest dwuznaczny. Można

${ }^{1}$ Tak zapewne myślą autorzy, którzy używają terminu „państwo prawne” w swych publikacjach, np. H. Izdebski, Historia myśli politycznej i prawnej, Beck, Warszawa 1995, § 70, „Państwo prawne” - „państwo prawne i społeczne”. Nie bardzo zresztą wiadomo, dlaczego autor używa cudzysłowów w tytule $\S 70$, czy M. Pietrzak, Demokratyczne, świeckie państwo prawne, Wydawnictwo Prawnicze PWN, Warszawa 2003 (jest to zbiór wcześniej opublikowanych artykułów, w których tytułach nazwa „państwo prawne” pojawia się). Zaznaczam, że moja uwaga jest wyłącznie terminologiczna, a nie wskazuje na jakiś błąd merytoryczny. Niemniej jednak uważam, że terminologia powinna być poprawna. Termin „państwo prawa” zaczął być częściej używany w ostatnich latach. 
go tłumaczyć jako „stan prawny”, co nie ma żadnego związku z rozważanym tematem lub, korzystając ze specyfiki przymiotników angielskich jako ukrytych rzeczowników, oddawać właśnie jako „państwo prawa”. Tak czy inaczej, terminologia zagraniczna nie uprawnia do posługiwania się frazą ,państwo prawne" jako polskim thumaczeniem słowa Rechtsstaat. Z drugiej strony, rozbieżności w nazewnictwie skłaniają do porównań. Będzie o tym mowa w końcowej części niniejszego artykułu.

Następujący argument sugeruje, że wspomniana konwencja terminologiczna identyfikująca państwo prawa z państwem prawnym jest watpliwa. Dobrym sposobem ustalania znaczeń lub przynajmniej orientowania się $\mathrm{w}$ dystynkcjach i intuicjach pojęciowych jest zestawianie słów (pojęć) z ich antonimami, czyli przeciwstawieniami co do sensu. Rozumiemy wolność, gdy z grubsza wiemy, kiedy trzeba wskazać na niewolę; sprawiedliwość, gdy wskazujemy na przypadki niesprawiedliwości (a nie na prawdziwą sprawiedliwość); czy też, aby użyć przykładu filozoficznego, rozumiemy, co to jest idealizm, gdy kontrastujemy go $\mathrm{z}$ realizmem lub (w innym znaczeniu) z materializmem. Trzeba tedy pytać, czemu przeciwstawia się państwo prawa. Jasne, że państwu bezprawia a nie państwu bezprawnemu. To drugie, o ile miałoby być rozumiane dosłownie, wygląda na dość osobliwą kategorię. Bezprawne, to jest jakie? Niemające cechy prawności? Niebędące podmiotem prawa międzynarodowego? Nieuznane przez inne państwa? Powstałe w sposób bezprawny? Możliwości interpretacyjnych jest zapewne więcej, ale nie będę rozwijał tej kwestii. W każdym razie każda z już wskazanych (i prawdopodobnie innych) wykładni jest na tyle niejasna, że w ogóle nie warto stosować terminu ,państwo prawne”, skoro można posłużyć się stosownym opisem, np. kiedy dany organizm polityczny nie jest podmiotem prawa międzynarodowego. Natomiast nazwa „państwo prawa” jest dlatego właściwa, iż wiadomo z czym ją kontrastować. Jest jeszcze drugi problem językowy związany z nazwą użytą w polskiej ustawie zasadniczej, mianowicie zasadności przydawki „demokratyczne” w kontekście „demokratyczne państwo prawa". Na razie tylko zaznaczam tę kwestię, ponieważ jej rozpatrzenie wymaga uprzedniego przedstawienia ewolucji pojęcia państwa prawa. Powyższe uwagi wskazują na filozoficzną motywację leżącą u podstaw mojej analizy pojęcia państwa prawa, ponieważ analiza semantyczna pojęć jest zawsze robotą filozoficzną. Wszelako intencja zaznaczona przez drugą część tytułu niniejszego artykułu nie sprowadza się tylko do kwestii terminologiczno-definicyjnych. W samej rzeczy, koncepcja państwa prawa pojawiła się w niemieckiej myśli polityczno-prawnej pierwszej połowy XIX w. pod wyraźnym wpływem filozofów, w szczególności, Kanta, Fichtego i Hegla. Postaram się pokazać, że od początku tkwiły w tej idei treści i napięcia charakterystyczne dla niemieckiej filozofii pokantowskiej. W szczególności, pytano, czy cechy państwa prawa są redukowalne wyłącznie do kryteriów czysto formalnych, czy też w jego pojęciu zawiera się coś jeszcze. 
Wiele czynników politycznych, ustrojowych i ideowych przyczyniło się do powstania koncepcji państwa prawa $\mathrm{w}$ Niemczech, a dokładniej mówiąc w państwach niemieckich, ponieważ pojawiła się ona na długo przed zjednoczeniem w jednolitą Rzeszę ${ }^{2}$. Koncepcja ta wyrosła $\mathrm{z}$ ducha oświeceniowego (w wydaniu niemieckim) i jej głównym przesłaniem była ochrona jednostki przed samowolą absolutnej władzy monarszej. Zadanie to przeznaczono państwu i prawu, przede wszystkim w odniesieniu do jego roli jako podstawy funkcjonowania władzy państwowej. Jeśli zaś chodzi o konkretne przyczyny polityczne i ustrojowe, wymienić można następujące (kolejność nie znaczy porządku istotności; lista nie pretenduje do kompletności): przemiany w koncepcjach zarządzania państwem, w szczególności wzrost roli administracji i jej biurokratyzację (w sensie technicznym, nie oceniającym), wpływ Rewolucji Francuskiej i konstytucjonalizmu, tzw. pruska droga do kapitalizmu i tendencje zjednoczeniowe w Niemczech. Do czynników ideowych zaliczam doktryny filozoficzne i silne poczucie Niemców, że w obliczu zmian spowodowanych przez wydarzenia XVIII w., które doprowadziły do konstelacji politycznej po wojnach napoleońskich trzeba iść własną drogą. Konkretnym przykładem realizacji tej drugiej tendencji była reforma niemieckiego systemu edukacyjnego zaprojektowana przez Wilhelma von Humboldta (także żywo zainteresowanego kwestiami politycznymi i niekiedy wręcz uważanego za teoretyka państwa prawa). Jednym z produktów wspomnianej reformy była idea deutsche Gelehrte, tj. dobrze wykształconego obywatela nie gorszego od mieszkańca Francji czy Wielkiej Brytanii. W szczególności, uczony niemiecki winien być zdolny do skutecznego konkurowania na polu odkryć naukowych ze swymi zagranicznymi kolegami. Mówiąc bardzo ogólnie, koncepcja państwa prawa była pomyślana jako alternatywa dla nowinek ustrojowych rodem z Francji czy Anglii, np. zasady podziału władz czy monarchii konstytucyjnej. Wyrażało się to także postępującą odmiennością, od początków XIX w., w pojmowaniu obywatelstwa, we Francji wedle przynależności państwowej, a w Niemczech wedle kryteriów narodowościowych. Nie znaczy to, że nie było analogii i to bardzo dużych pomiędzy problematyką państwa prawa a problematyką praworządności (por. uwagi na końcu artykułu).

Jak już wspomniałem Kant, Fichte i Hegel byli tymi filozofami, którzy istotnie zaważyli na koncepcji państwa prawa ${ }^{3}$. Kant, najważniejszy z tej trójcy w tym względzie, rozważał filozofię polityczną, w tym państwa i prawa, w ra-

${ }^{2}$ Dobrym przeglądem kwestii ustrojowych jest artykuł A. Dziadzio, Koncepcja państwa prawa w XIX w. Idea i rzeczywistość, „Czasopismo Prawno-Historyczne” LXVII(2005), z. 1, s. 177-201.

${ }^{3}$ Ponieważ artykuł ten nie pretenduje do analizy czy interpretacji myśli politycznej tych myślicieli, moje uwagi na temat ich poglądów są skrótowe i elementarne, tylko wyjątkowo dotykam kwestii interpretacyjnych. Dlatego w zasadzie nie cytuję źródeł. Taki sposób przedstawienia filozoficznego kontekstu koncepcji państwa prawa jest uzasadniony tym, że prawnicy nawet gdy korzystają z doktryn filozoficznych, czynią to w sposób selektywny i ogólny. 
mach tzw. krytyki rozumu praktycznego. Starał się sformułować (lepiej powiedzieć, że, wedle własnego mniemania, po prostu odkrywał je) aprioryczne podstawy funkcjonowania państwa i prawa. Organizacje państwową uważał za wspólnotę (Vereinigung) ludzi poddaną prawu. Ponieważ zasady prawa wypływają z rozumu, można powiedzieć, że wedle Kanta państwo jest wspólnotą ludzi zorganizowaną wedle zasad rozumu. Od tego był już tylko krok do tezy (Kant jej nie wypowiedział explicite), że państwo jako takie jest, a nawet musi być racjonalne. Państwo wedle Kanta realizuje prawo, które jest oparte na przymusie zewnętrznym i w tym sensie jest heteronomiczne, czyli mające zewnętrzną podstawę dla swego obowiązywania. Natomiast moralność jest autonomiczna (,prawo moralne we mnie") i ugruntowana w ludzkiej dobrej woli, wolnej właśnie jako wola i przez to wnoszącej wolność do świata. Zadaniem prawa jest uzgodnienie wolności jednostki z wolnością współobywateli, a więc niejako synteza autonomii i heteronomii, co ma na celu ograniczenie czy nawet wyeliminowanie samowoli. Inaczej mówiąc, prawo jest gwarantem wolności obywatelskiej, czyli dla wszystkich. Rozwiązanie Kanta polegało więc na zrównoważeniu wolności jednostki i wolności zbiorowości. Tej drugiej rozumianej jako fundament interesu ogólnego. Wprawdzie Kant odróżniał wolność od czegoś i wolność do czegoś, ale autonomia jednostki zasadzała się na pierwszej, a w państwie rozumianym jako realizacja królestwa celów prowadziła do drugiej.

Fichte i Hegel rozwinęli kantowską ideę racjonalności państwa w kierunku kolektywistycznym. Pierwszy w swych sławnych Mowach do narodu niemieckiego, napisanych w czasie wojen napoleońskich (dokładnie w 1808 r.), zapoczątkował mesjanizm niemiecki jako narodowy program odnowy moralnej. Naturalnym postulatem w tym związku było wezwanie do zjednoczenia narodu jako wspólnoty duchowej a nie tylko ogółu mieszkańców określonego terytorium. Chociaż Fichte także kładł nacisk na wolność jednostki, równocześnie podporządkowywał ją interesom wspólnoty, a nie tylko, jak Kant, uprawnieniom innych jednostek. Wolność do czegoś nie realizuje się, jak w przypadku filozofa z Królewca, jako rezultat wolności od czegoś, ale musi się dokonać moralnie uświadomionym czynem, zgodnie z Fichtego filozofią aktywnego podmiotu działania. Państwo jako organizacja wspólnoty realizuje wolność, a najlepiej to zrobi, gdy będzie zamknięte i samowystarczalne. Hegel traktował państwo jako najwyższe wcielenie ducha obiektywnego, czyli idei. Dzięki temu państwo jest racjonalne, by tak rzec, samo w sobie, a nie na mocy postulatu rozumu praktycznego jak w koncepcji Kanta. Wedle Hegla, społeczeństwo zorganizowane w państwo nie może być tylko luźnym zbiorem jednostek, ale jest wspólnotą, gdyż właśnie taka obiektywizuje wolność w tym przypadku do czegoś. Hegel jako pierwszy utożsamił społeczeństwo (Gesellschaft) z Gemeinschaft, czyli wspólnotą z uwagi na wspólną kulturę duchową i w ten sposób dokończył dzieła Fichtego. Taka wspólnota jest całością pierwotną wobec 
jednostek, a przez to staje się tzw. społeczeństwem cywilnym, czyli obywatelskim, społeczeństwem dla siebie, tj. świadomym swej wolności, a nie tylko w sobie, czyli jako grupy naturalnie wyodrębnionych jednostek, istniejących oddzielnie.

Kant, jak wiadomo, wyraźnie oddzielił byt (sferę faktyczności) od powinności (sfery normatywnej). Pytanie, do której sfery należy państwo jako zbiorowość poddana rozumowi, nie ma wyraźnego rozstrzygnięcia na gruncie filozofii kantowskiej. Ewolucja myśli neokantowskiej, powstałej w drugiej połowie XIX w., polegała na coraz większym podkreślaniu roli czynnika normatywnego aż do krańcowego ujęcia Hansa Kelsena, który utożsamił państwo z prawem. Fichte wprawdzie także oddzielał byt i powinność, ale ta druga była nieodłączna od racjonalności jako atrybutu transcendentalnego Ja, podstawowej kategorii fichteańskiej filozofii czynu. Jego program państwa zamkniętego był rzecz jasna utopią, podobną do starożytnego projektu Platona, ale Fichte argumentował, że tylko w ten sposób można urzeczywistnić racjonalność i powinność. Hegel niejako zniósł przeciwstawienie tego, co powinne i tego, co faktyczne (rzeczywiste). $Z$ jednej strony to, co rzeczywiste (istniejące) jest racjonalne, i na odwrót, to, co racjonalne jest rzeczywiste, a z drugiej strony zachodzi identyczność tego, co powinne i tego, co racjonalne. Hegel nie przejmował się tym, że realnie istniejące państwa były mniej lub bardziej dalekie od wymagań ducha obiektywnego. Być może, by sparafrazować jego znaną myśl, jeśli faktyczne państwo nie spełnia warunków racjonalności, tym gorzej dla faktów. Hegel mógł ewentualnie pocieszyć się tym, że znalazł (wedle swego mniemania) konkretyzację państwa jako wcielenia ducha obiektywnego w sobie współczesnym państwie pruskim. Przy wszystkich różnicach pomiędzy Kantem, Fichtem i Heglem oraz wieloznacznościach ich poglądów, wszyscy trzej podzielali przynajmniej jedno przekonanie na temat racjonalnego państwa, mianowicie, że nie może ono być złe. Jeśli tak jest, to należycie spełnia swe obowiązki wobec jednostek i wspólnoty. Z pewną dozą przesady można powiedzieć, że państwo i dobre (racjonalne) państwo są tym samym wedle Kanta, Fichtego i Hegla. Inaczej mówiąc, państwo odbiegające od wzorca racjonalności jest bytem niepełnym, podobnie jak to wcześniej było u Platona, gdzie państwo rządzone przez mędrców należało do świata idei, a jego mniej lub bardziej udane aproksymacje - do świata rzeczy. Konkretne kwestie ustrojowe miały dla tych myślicieli niezbyt wielkie znaczenie, np. Kant i Fichte opowiadali się za organami przedstawicielskimi, aczkolwiek w dość mglistym sensie, a Hegel, preferując monarchię, w ogóle ignorował zagadnienie wyborów. Z drugiej strony, Hegel podkreślał rolę konstytucji znacznie silniej, niż czynili to Kant i Fichte, ale to wcale znaczyło, że postulował monarchię konstytucyjna, np. w stylu brytyjskim. Jeszcze raz wypada powtórzyć, że Niemcy chcieli mieć własne koncepcje polityczne, o których oczywiście zakładali, że są lepsze od powstałych w innych krajach. 
Chociaż Kant, Fichte i Hegel współtworzyli intelektualny klimat dla koncepcji państwa prawa, pojawiła się ona w sposób wyraźny w prawniczej literaturze niemieckiej w początkach XIX w. Pierwszy rozwiną ją Carl Theodor Welcker w opracowaniu Die letzten Grundsätze von Recht, Staat und Strafe, Giessen 1813, a głównym jej teoretykiem stał się Robert von Mohl, autor m.in. dzieł: Die deutsche Polizeiwissenschaft nach den Grundsätzen des Rechtsstaates, Tübingen 1833 (groźnie wyglądające słowo Polizeiwissenschaft oznaczało wtedy naukę o administracji) i Enzyklopädie der Staatswissenschaften, Tübingen 1859 (wydanie polskie, Encyklopedia umiejętności politycznych, Wydawnictwo Liber, Warszawa 2003); ta druga książka jest do dzisiaj uważana za bodaj najważniejszy i najpełniejszy wykład zasad państwa prawa, a kombinacja deutsche Polizeiwissenschaft i Rechtsstaat w tytule pierwszego jest znacząca, głównie z uwagi na kwalifikację deutsche. Termin Rechtsstaat występował już okazjonalnie przed 1833 r., a nawet w końcu XVIII w. w tekstach wczesnych liberałów niemieckich na oznaczenie przeciwieństwa ustroju despotycznego uosabianego wówczas z monarchią absolutną, także, przynajmniej częściowo, z państwami funkcjonującymi w ramach absolutyzmu oświeconego ${ }^{4}$. Termin ten nie zdobył sobie jednak popularności do czasów von Mohla, pomimo tytułu w książce Welckera, o czym świadczy fakt, że odpowiedniego hasła nie ma w obszernym (6 tomów) Allgemeine Handwörterbuch der philosophischen Wissenschaften nebst ihrer Literatur und Geschichte, opracowanym przez Wilhelma Theodora Kruga w Lipsku w latach 1832-1838. Wszelako od połowy XIX w. kategoria państwa prawa weszła już na stałe do niemieckiej terminologii prawno-politycznej.

Jeśli chodzi o praktykę polityczno-ustrojową, to, pomijając takie czy inne antycypacje w niektórych krajach wchodzących w skład Związku Niemieckiego, a potem Związku Północno-Niemieckiego, zasady państwa prawa znalazły zastosowanie w Cesarstwie Niemieckim (II Rzeszy), Republice Weimarskiej i Republice Federalnej Niemiec. Te trzy, bardzo różne, organizmy państwowe są uważane, zwłaszcza w literaturze niemieckiej, za typowe przykłady realizujące ideę państwa prawa (kwestia Austrii zostanie omówiona później). Różnorodność wcieleń państwa prawa ilustruje bardzo ważny fakt, mianowicie, że Rechtsstaat nie jest formą państwa w technicznym rozumieniu tego pojęcia stosowanego wówczas głównie dla przeciwstawienia monarchii republice, ale takim stanem spraw w obrębie organizacji państwowej, w którym respektowane są określone zasady regulujące relacje pomiędzy jednostką a władzą, w każdym razie takie, które wykluczają arbitralne poczynania państwa wobec jednostek. Ideologia związana z państwem prawa koncentruje się na celu państwa, a nie na jego kon-

\footnotetext{
${ }^{4}$ Por. E.-W. Böckenförde, Rechtsstaat, w: Historisches Wörterbuch der Philosophie, hrs. von J. Ritter und K. Gründer, Band 8: R-Sc, Wissenschaftliche Buchgesellschaft, Darmstadt 1992, s. 332-342.
} 
kretnym ustroju. Koresponduje to z poglądami Kanta, Fichtego i Hegla, którzy nie przykładali (patrz wyżej) zbytniej wagi do tego, czy racjonalne państwo ma taki czy inny ustrój. Rechtsstaat może być monarchią lub nie, mieć konstytucję lub nie, natomiast u podstaw jego funkcjonowania leży pewien cel, mianowicie ochrona wolności jednostek, ale tak, aby to nie kolidowało z funkcjami państwa.

Chociaż pierwsi teoretycy Rechtsstaat niemal powtarzali tezy Kanta, gdy powiadali - jak Welcker - że państwo prawa jest państwem rozumu, to nie wystarczało do wyprowadzenia listy konkretnych uregulowań. Ogólne założenia, że celem państwa jest ochrona obywateli i to, że prawu powinny podlegać wszystkie sfery życia publicznego, wprawdzie uszczegółowiały wymagania rozumu praktycznego w odniesieniu do państwa, ale nie w taki sposób, aby wynikały z nich bardziej szczegółowe zasady, może poza postulatem, aby obywatele mieli zapewnioną ochronę przez sądy. Klasyczne sformułowanie detali państwa prawa pochodzi od von Mohla i, wedle typowej rekonstrukcji, obejmuje następujące punkty ${ }^{5}$ :

(1) prawo do życia;

(2) dozwolone jest to, co nie jest zakazane;

(3) równy udział w sprawach publicznych;

(4) wolność osobista;

(5) wolność myśli;

(6) wolność wyznania;

(7) prawo przenoszenia się z miejsca na miejsce;

(8) swoboda zakładania stowarzyszeń, o ile mają one na celu działania dozwolone i nieszkodzące ogółowi.

Katalog ten stwarzał od początku pewne problemy interpretacyjne. Postulowana jurydyzacja życia publicznego prowadziła do kwestii, którą anegdotycznie i nieco żartobliwie ujmuje następujące porównanie: W Anglii, typowym kraju liberalnym, (2) jest brane dosłownie, a w Niemczech rozumiane jako zasada „dozwolone jest to, co jest wyraźnie dozwolone”. Rozumienie relacji pomiędzy tym, co dozwolone a tym, co zakazane nie jest bez znaczenia dla interpretacji ogólnego postulatu jurydyzacji życia publicznego, a z kwestii szczegółowych punktu (8). Czytelnika Encyklopedii umiejętności politycznych może np. uderzać nacisk, jaki von Mohl kładzie na to, aby obywatele realizowali swe wolności w sposób prawnie uregulowany. Jeśli uznać ten aspekt życia publicznego za charakterystyczny rys mentalności niemieckiej, to pierwszy program państwa prawa ją odzwierciedla niemal modelowo.

Dwa inne poglądy von Mohla są ważne z uwagi na dalsze losy koncepcji państwa prawa, przynajmniej do czasów Republiki Weimarskiej. Zdefiniował

\footnotetext{
${ }^{5}$ Podaję (w nieco odmiennych sformułowaniach) za A. Bosiackim, „Wstęp”, w: R. von Mohl, Encyklopedia umiejętności politycznych, thum. A. Białecki, Liber, Warszawa 2003, s. XXXIV. Autor wstępu i thumacz posługują się terminem ,państwo prawne”.
} 
on państwo jako „trwały, jednolity organizm takich urządzeń, które kierowane zbiorową wolą, a utrzymywane i przeprowadzane zbiorową siłą, mają za zadanie wspierać dozwolone cele życia pewnego na ograniczonej przestrzeni osiedlonego narodu, zaczynając od indywidum aż do towarzystwa"6. Przez towarzystwo (a raczej to, co thumacz tak oddał) von Mohl rozumiał, to co dzisiaj nazywa się społeczeństwem (Gesellschaft). Ma to być przy tym społeczeństwo cywilne w sensie Hegla, który jest cytowany w odpowiednim miejscu Encyklopedii umiejętności politycznych. Von Mohl skrytykował przy okazji rozmaite koncepcje państwa, np. utylitarystyczną (Bentham), wedle której państwo ma uszczęśliwiać ludzi, eschatologiczną (De Maistre), taktująca państwo jako niepełne przybliżenie królestwa Bożego, i nawet heglowską, którą rozumiał jako postulat zaprowadzenia moralnej jedności w życiu. Krytyka obcych doktryn, zwłaszcza francuskich nie dziwi, zważywszy niemieckie ambicje konkurowania z innymi nacjami. Może dlatego von Mohl całkowicie przeoczył liberalne konsekwencje utylitaryzmu (liberałowie brytyjscy mogli bez większych zastrzeżeń zaakceptować punkty (1)-(8)) i to, że Hegel kładł nacisk na pogodzenie morale obywatela i państwo, a więc w zasadzie na to samo, co wyraża ostatni z postulatów von Mohla. W samej rzeczy, apel do zbiorowej woli i zbiorowej siły u von Mohla jest jak najbardziej w duchu idei Fichtego i Hegla. Przytoczona definicja państwa wspomina o narodzie. Von Mohl powiada, że „ogół uczestników państwa tworzy lud, czyli naród”7. Znajdujemy tutaj wyraźne wykorzystanie wspomnianej wcześniej niemieckiej, tj. narodowościowej koncepcji obywatelstwa. W związku z narodem pojawia się kwestia jego pochodzenia, a także rasy. Von Mohl nie zakłada nierówności ras jako zasady, ale też jej nie wyklucza. Wskazuje na zależność życia zbiorowości określonych rasowo, np. od warunków klimatycznych czy innych okoliczności środowiskowych i kulturowych oraz utrzymuje, że „rasy i właściwości plemienne wyrabiają odpowiedni sposób życia, a za nim rozmaite upodobania"8. Konkluduje, że na bieg spraw w państwie wpływ mają zewnętrzne i wewnętrzne podziały narodowościowe. Wprawdzie nie stwierdza, że państwo jednonarodowe jest lepsze od wielonarodowego, ale trudno oprzeć się wrażeniu, że w jego sformułowaniach dźwięczą nuty nieco przypominające Fichtego postulat państwa zamkniętego, aczkolwiek von Mohl jest bardzo daleki od propozycji trącących utopią. Podkreślając aktywną rolę państwa i prawa w życiu społecznym, von Mohl odrzucał model państwa „stróża nocnego”, a więc jedną z charakterystycznych doktryn liberalizmu angielskiego.

Łatwo zauważyć, że zasady (1)-(8) dopuszczają rozmaite interpretacje, nawet taką, która sankcjonuje niemiecki nacjonalizm, przynajmniej w jego dzie-

\footnotetext{
${ }^{6}$ R. von Mohl, Encyklopedia umiejętności politycznych, s. 65 .

${ }^{7}$ Ibidem, s. 111.

${ }^{8}$ Ibidem, s. 113.
} 
więtnastowiecznej formie. Trudno się zresztą temu dziwić, skoro Kant, Fichte i Hegel, a zwłaszcza dwaj ostatni myśliciele, bywają uważani za prekursorów postawy nacjonalistycznej. Jest to dość interesujący moment $\mathrm{z}$ uwagi na związek koncepcji państwa prawa z filozofia, ale dyskusja tej kwestii przekracza ramy niniejszego artykułu. Niemiecka debata na temat Rechtsstaat w drugiej połowie XIX w. koncentrowała się na zasadach funkcjonowania państwa prawa ${ }^{9}$. Mówiąc bardzo ogólnie, coraz bardziej podkreślano formalne reguły organizujące ten rodzaj organizacji państwowej. To zrozumiałe, skoro rzeczona debata toczyła się w okresie dominacji pozytywizmu prawniczego. Von Mohl nie był pozytywistą czy też nie reprezentował radykalnej wersji tego kierunku, ale jego teza o podległości życia publicznego prawu obowiązującemu w państwie skłaniała do pozytywistycznej interpretacji tego stanu rzeczy. Racjonalność prawa i państwa zaczęto rozumieć jako per se, niezależną od jego treści, a więc w sposób charakterystyczny dla filozofii Kanta i jego następców. Trzeba jednak tutaj dodać istotne zastrzeżenie. Wiek XIX był epoką optymizmu poznawczego i aksjologicznego. Nie brano na serio pod uwage możliwości jakoby państwo i prawo mogły służyć celom złym czy niegodziwym. Uważano, że prawo, a zatem i państwo, ponieważ oba pozostają ze sobą w ścisłym związku, są wyposażone, by użyć nieco bardziej współczesnego języka, w wewnętrzną moralność w zasadzie uniemożliwiającą złe cele państwa i ich realizację. Pouczające są w tym względzie dyskusje nad Królestwem Prus po 1850 r. czy II Rzeszą. Podczas gdy dla jednych ustawodawstwo antysocjalistyczne, Kulturkampf, ograniczenia wolności wyznania wobec katolików i silna niezależność władzy wykonawczej od ustawodawczej stanowiły zaprzeczenie państwa prawa, dla innych były to tylko doraźne restrykcje wobec praw niektórych obywateli, wprawdzie uciążliwe, ale umocowane narodową wolą zbiorowa. W rezultacie rządy Wilhelma I i Wilhelma II bywają kwalifikowane albo jako Polizeistaat (państwo policyjne), albo jako państwo prawa. Jeśli przyjmie się ten drugi punkt widzenia, koncepcja Rechstaat staje się nader pojemna. Zwykle uważa się to za wynik formalnej (pozytywistycznej) koncepcji państwa prawa, ale wpływ klasycznych niemieckich doktryn filozoficznych też miał w tym swój walny udział.

Czy Austria była państwem prawa w XIX w. i po konstytucji z 1920 r.? ${ }^{10}$ Pytanie to jest zasadne z kilku powodów. Jest to przecież kraj niemieckojęzyczny, przez wielu uważany za część Wielkich Niemiec. Pozostawał on przez stulecia w rozmaitych związkach kulturowych i politycznych z resztą Świętego Cesarstwa Rzymskiego Narodu Niemieckiego, w szczególności był wielekroć politycznym sojusznikiem innych państw niemieckich, chociaż też walczył z Prusami o hegemonię w świecie niemieckim w XIX w., w końcu zdecydowanie

\footnotetext{
${ }^{9}$ Por. artykuły cytowane w przyp. 2 i 4.

${ }^{10} \mathrm{~A}$. Dziadzio udziela pozytywnej odpowiedzi na to pytanie.
} 
przegrywając. Miał za sobą, podobnie jak Prusy, okres absolutyzmu oświeconego, uważany przez radykalnych liberałów, jeśli chodzi o panujący wtedy ustrój, za przykład Polizeistaat (system józefiński w Austrii, system fryderycjański w Prusach). Oba państwa podlegały reżimowi konserwatywnej reakcji po kongresie wiedeńskim. Austria zaczęła się liberalizować nieco później niż Prusy, ale mniej więcej w tym samym okresie. Stosowne programy reform zostały wprowadzone $\mathrm{w}$ obu przypadkach $\mathrm{w}$ ramach ustroju monarchicznego, przy czym monarchia naddunajska uczyniła to głębiej i radykalniej niż II Rzesza, np. w sprawach narodowościowych. I wreszcie, Republika Austriacka po I wojnie światowej i Republika Weimarska były nie tylko do siebie podobne ustrojowo, ale obie w końcu podzieliły ten sam los historyczny, a stało się to z tych samych powodów. Nie mam gotowej odpowiedzi na postawione pytanie. Wszelako chciałbym zwrócić uwagę na to, że austriacka teoria państwa rozwijała się odmiennie niż niemiecka. Okoliczności polityczne sprawiły, że władze austriackie świadomie ograniczały wpływ tzw. klasycznej filozofii niemieckiej w swoim kraju. Idee Kanta, Fichtego i Hegla nie wywarły zatem większego wpływu na doktryny polityczne nauczane i rozpowszechniane w monarchii habsburskiej. Ponadto, wielonarodowość Cesarstwa Austriackiego sprawiła, że pojęcie woli zbiorowej jako wyrazu narodu, rekomendowane przez von Mohla, nie miało żadnego zastosowania do rzeczywistości pod rządami Franciszka Józefa I, a więc wtedy, gdy liberalne reformy zostały wdrożone. Jeśli uznać Ludwika Gumplowicza i Antona Mengera za typowych przedstawicieli austriackiej teorii państwa, byli oni bardziej zwolennikami socjologizmu niż pozytywizmu reprezentowanego przez Jerzego Jellinka w Niemczech.

Być może wolno powiedzieć, że jeśli koncepcja państwa prawa ma rys rdzennie niemiecki, wyrażający się w jej kontekście filozoficznym, to Austria nie jest typowym wcieleniem Rechtsstaat, ale można bronić przeciwnego stanowiska, gdy ograniczymy się tylko do katalogu (1)-(8). Wszelako punkty te charakteryzują bardzo ogólny liberalizm polityczny, niekoniecznie związany $\mathrm{z}$ ideowym kontekstem koncepcji państwa prawa w wydaniu niemieckim. Pozytywizm prawniczy pojawił się w Austrii dopiero za sprawą Kelsena, skądinąd twórcy konstytucji z 1920 r. Chociaż pozostawał on pod wpływem neokantyzmu, to $z$ drugiej strony całkowicie odrzucał filozofię Fichtego i Hegla. Nawet jeśli udzieli się twierdzącej odpowiedzi na pytanie, czy Austria była państwem prawa pod koniec XIX w., warto pamiętać o wskazanych odrębnościach. Interesujące różnice pomiędzy Francją, Prusami i Austrią dotyczą relacji pomiędzy kodeksami, ogólnymi wolnościami i prawami jednostek (indywidualnymi $)^{11}$. Model francuski odpowiada schematowi (strzałki ilustrują

${ }^{11}$ D. Canale, The Many Faces of the Codification of Law in Modern Continental Europe, w: A History of the Philosophy of Law in the Civil Law World, 1600-1900 (A Treatise of the Legal Philosophy and General Jurisprudence, ed. by E. Pattaro, v. 9), ed. by D. Canale, P. Grossi, Hasso Hofmann, Springer, Dordrecht 2009, s. 159, 171, 179. 
determinowanie): kodeksy prawa pozytywnego $\rightarrow$ równość/wolność $\rightarrow$ prawa indywidualne; pruski zaś sekwencji: równość/wolność $\rightarrow$ kodeksy prawa pozytywnego $\rightarrow$ prawa indywidualne, natomiast austriacki przyjmuje taką kolejność: prawa indywidualne $\rightarrow$ wolność/równość $\rightarrow$ kodeksy prawa pozytywnego. Różnica pomiędzy modelem austriackim i pruskim (francuski nie jest tutaj istotny) od razu rzuca się w oczy. Rozwiązanie pruskie (także niemieckie aż do Republiki Weimarskiej włącznie) wprawdzie zakłada priorytet wolności i równości, ale obie te wartości są mediowane przez kodeksy prawa pozytywnego. Natomiast model austriacki wywodzi wolność i równość z praw jednostki, a prawo pozytywne ma to odzwierciedlać. Jeśli ten obraz jest poprawny, od razu znajdujemy charakterystyczny rys niemieckiej koncepcji państwa prawa, mianowicie bardzo formalne podejście do wolności, równości i praw indywidualnych.

Republika Weimarska, kolejny historyczny etap państwa prawa na terenie Niemiec, była państwem demokratycznym o ustroju parlamentarno-gabinetowym. Jej konstytucja z 1919 r. wprowadziła szeroki wachlarz praw obywatelskich. Miało to zapobiec pojawieniu się wspomnianych wyżej odstępstw Cesarstwa Niemieckiego od modelowych rozwiązań w duchu państwa prawa. Dodatkowo doktryna polityczna zakładana przez twórców Republiki Weimarskiej traktowała wprawdzie naród jako źródło władzy, ale równocześnie zdecydowanie odcinała się od idei wspólnoty narodowej w sensie Fichtego czy Hegla. Architekci systemu weimarskiego byli jednak przeświadczeni o tym, że II Rzesza mimo takich czy innych niedostatków była państwem respektującym prawo i dlatego nie widzieli powodu dla rewizji pozytywistycznej teorii stosowania prawa. Być może był to refleks kilkakrotnie już wspomnianego założenia o wewnętrznej racjonalności należycie sformułowanego i ustanowionego prawa. Republika Weimarska była krytykowana przez komunistów i socjaldemokratów za obojętność w sprawach socjalnych, a przez narodowych socjalistów za ignorowanie kwestii narodowej w bardziej nacjonalistycznym rozumieniu. Zarówno obrońcy systemu weimarskiego, jak i krytycy z obu stron mogli się odwołać do tradycji dziewiętnastowiecznej, pierwsi do formalnego rozumienia państwa prawa $\mathrm{w}$ wersji pozytywistycznej, socjaldemokraci i komuniści - do celów i funkcji państwa wykraczających poza ideę nocnego stróżowania, czyli tylko i wyłącznie zapobiegania przestępstwom, a narodowi socjaliści - do elementów nacjonalizmu u Fichtego i Hegla, także widocznych w programie Rechtsstaat. W każdym razie, krytycy systemu weimarskiego mieli powody, aby uważać, że zdradza on, przynajmniej w pewnych punktach, tradycję niemiecką i jest, jak mówiono, państwem bez treści. Tak czy inaczej, system polityczny Republiki Weimarskiej nie zapobiegł demokratycznemu (w drodze najzupełniej normalnych i wiarygodnych wyborów) przejęciu władzy przez Hitlera. Wtedy dopiero program narodowego socjalizmu ujawnił się w pełni jako skrajnie antyliberalny, takożsamo nacjonalistyczny i autorytar- 
ny. I tak państwo prawa legalnie i demokratycznie przekształciło się w państwo bezprawia na niespotykaną dotąd skalę.

Jednym z naczelnych zadań niemieckiej doktryny prawniczej po II wojnie światowej stał się rozrachunek z tym, co wydarzyło się w latach 1933-1945. Głównym eksponentem tej tendencji od strony teoretycznej stał się Gustaw Radbruch, dwukrotny minister sprawiedliwości w początkowym okresie Republiki Weimarskiej i profesor uniwersytetu w Heidelbergu w latach 1926-1933 i po 1945 r. Radbruch był zwolennikiem neokantyzmu badeńskiego, co w filozofii prawa oznaczało szereg punktów wspólnych z pozytywizmem, zwłaszcza rozdzielenie sfery bytu i powinności. Z drugiej strony, neokantyści nie wykluczali myślenia o prawie w kategoriach aksjologicznych, aczkolwiek byli skłonni oddzielać wartość prawa od jego obowiązywania. Radbruch zrewidował swoje poglądy po II wojnie światowej i odszedł od pozytywizmu (pomijam często dyskutowaną kwestię na ile był pozytywista, a na ile przedstawicielem doktryny prawno-naturalnej). Uznał, że pozytywistyczne wychowanie prawników niemieckich znieczuliło ich na państwo bezprawia i w ten sposób przyczyniło się do sukcesu nazizmu w postaci przejęcia władzy w Niemczech. Radbruch zakwestionował pozytywistyczne utożsamienie prawa i ustawy, gdyż to prowadzi do tzw. ustawowego bezprawia, powszechnego w III Rzeszy. Wprowadził (w 1946 r.) słynną formułę lex iniustissima non est lex, czyli, że prawo rażąco niesprawiedliwe nie jest prawem. Często jest ona interpretowana w ten sposób, że nie obowiązuje prawo (lex) rażąco sprzeczne z prawem natury. Można i tak, ale Radbruch miał na myśli raczej to, że ustawa wyraźnie niespełniająca wymogów sprawiedliwości nie może być uznana za prawo, nawet jeśli została wydana zgodnie $\mathrm{z}$ wymogami formalnymi. Formuła Radbrucha miała na celu oddalenie argumentu, że funkcjonariusze III Rzeszy działali legalnie, ponieważ stosowali prawo obowiązujące w tym państwie, a więc ustanowione zgodnie z procedurami tego kraju. Podobna idea leżała u podstaw działania Międzynarodowego Trybunału Sprawiedliwości w Norymberdze i została zastosowana $\mathrm{w}$ licznych procesach przeciwko osobom odpowiedzialnym za zbrodnie II wojny światowej. Od strony doktrynalnej Radbruch niewątpliwie postulował pewien kompromis pomiędzy prawem natury a pozytywizmem prawniczym, który można wyrazić zasadą tylko iusta lex est lex. Filozof prawa nie może oczywiście powstrzymać się od pytania o efektywne kryteria sprawiedliwości czy rażącej niesprawiedliwości, ale to inna sprawa, którą tutaj tylko zaznaczam.

Koncepcja państwa prawa przyjęta w Ustawie Zasadniczej Republiki Federalnej Niemieć (taka jest oficjalna nazwa tego aktu, aczkolwiek jest to konstytucja w zwyczajowym rozumieniu) z 1949 r. jest pod przemożnym wpływem postulatów Radbrucha. Po pierwsze, uznaje godność człowieka za prawo najbardziej podstawowe i nienaruszalne, rozszerza katalog pozostałych praw obywatelskich oraz wprowadza prawa socjalne. Obie grupy konstytuują zespół 
praw człowieka, które są uznane za niezbywalną esencję ładu demokratycznego. Po drugie, konstytucja niemiecka wprowadza rozmaite gwarancje praw człowieka. Należą do nich w szczególności: podział władz (detale tzw. systemu są nieistotne z punktu widzenia dyskutowanej kwestii), szerokie uprawnienia dla Federalnego Trybunału Konstytucyjnego, zwłaszcza w zakresie kontroli zgodności ustaw z Ustawą Zasadniczą oraz tzw. klauzulę wieczności (w sensie niepodlegania zmianie, przynajmniej w Ustawie Zasadniczej; ,,przynajmniej" zaznacza, że akt z 1949 r. przewiduje uchwalenie nowej konstytucji po zjednoczeniu Niemiec) podstawowych praw człowieka. Oficjalne komentarze do konstytucji z 1949 r. wskazują z jednej strony na to, że nawiązuje ona do tradycji niemieckiej od połowy XIX w. (tzw. konstytucja frankfurcka) i systemu weimarskiego, ale z drugiej strony, że korzysta z tragicznych doświadczeń lat 1933-1945 tak, aby więcej się nie powtórzyły. Interesujące jest to, że konstytucja RFN odeszła do czysto narodowościowej definicji obywatelstwa na rzecz państwowej, aczkolwiek, podobnie jak konstytucja Republiki Weimarskiej, uważa Naród za źródło władzy. Można to uznać za zdecydowane zerwanie z tradycją Fichtego i Hegla, a zwłaszcza jej nacjonalistyczną interpretacją. Jako ciekawostkę można przytoczyć fakt, że Ustawa Zasadnicza powiada o wolności przemieszczania się jako o prawie podstawowym, tak jak to było u von Mohla.

Od strony doktrynalnej i niezależnie od konkretnych rozwiązań niemieckich, bo idea Rechtsstaat stała się uniwersalna, państwo prawa, tak jak jest ono pojmowane współcześnie, może być scharakteryzowane przez następujące punkty:

(a) działania państwa mają być oparte na koherentnym systemie prawa;

(b) prawo ma strukturę hierarchiczną z konstytucją jako elementem najwyższym;

(c) niższe akty prawne muszą być zgodne z wyższymi;

(d) władza ustawodawcza, wykonawcza i sądownicza są rozdzielone;

(e) ustawy wydawane są przez parlamenty, a inne akty prawne mają na celu wykonanie ustaw;

(f) sądy są niezawisłe;

(g) działania organów państwowych, przede wszystkim administracyjnych, są poddane kontroli, także sądowej (sądownictwo administracyjne, trybunały konstytucyjne);

(h) obowiązuje zasada, że co nie jest zakazane, jest dozwolone;

(i) prawo wyszczególnia i gwarantuje rozmaite wolności obywatelskie czy prawa człowieka, które stanowią nieprzekraczalną granicę interwencji państwa w życie obywateli;

(j) jeśli niezbędne są ograniczenia swobód, powinny być one ściśle przewidziane przez system prawny i traktowane jako wyjątki dopuszczalne tylko w stanie wyższej konieczności. 
Powyższe postulaty określają pewien model państwa prawa (Kant powiedziałby, że jest to idea regulatywna, ale obecna teoria polityczna nie stosuje tej charakterystyki). Nie należy mieć rzecz jasna złudzeń, że model ten jest gdziekolwiek zrealizowany w stu procentach, czy też, że może doczekać się pełnego urzeczywistnienia, a nawet wykluczyć, że nie powtórzy się historia z końca Republiki Weimarskiej. W samej rzeczy, sławny logik austriacki Kurt Gödel, gdy przygotowywał się do egzaminu z konstytucji amerykańskiej wymaganego w związku ze staraniem się o obywatelstwo USA, stwierdził, że jej zasady nie uniemożliwiają wprowadzenia dyktatury w Stanach Zjednoczonych Ameryki, aczkolwiek jego diagnoza dotyczyła amerykańskiej demokracji a nie niemieckiego państwa prawa. Być może korzystał ze swego doświadczenia jako obywatela Austrii, a potem III Rzeszy. Nie jest zresztą rzeczą wymierna, jaki stopień odstępstw od postulatów (a)-(j) już unicestwia realizację Rechtsstaat lub jeszcze uprawnia do stosowania tej nazwy wobec jakiegoś konkretnego organizmu państwowego. Nie jest to zresztą nic nowego, aby przypomnieć (por. wyżej) dyskusje na wilhelmińskimi Niemcami jako państwem prawa.

Wracam do kwestii, czy trzeba używać nazwy „demokratyczne państwo prawa”. Zakładam, że przymiotnik „demokratyczne” został użyty w tekście polskiej konstytucji jako wskazujący na jakąś istotną (konstytutywną) cechę państwa prawa. Będę jednak argumentował, że w żadnym momencie ewolucji koncepcji Rechtsstaat nie było potrzeby stosowania terminu „,demokratyczne państwo prawa" jako wskazującą na istotę tego, co oznacza. Von Mohl nie przypisywał państwu prawa żadnej specjalnej formy, zgodnie zresztą z już wówczas (tj. w 1859 r.) ugruntowaną tradycją doktrynalną. Wspominając w §§ 44-48 Encyklopedii umiejętności politycznych o rodzajach państwa prawa, wymienia demokrację, arystokrację i monarchię. Skoro pojęcie państwa prawa jest rodzajowym, to z powodów czysto logicznych można ów rodzaj podzielić na różne sposoby, np. tak, jak to uczynił von Mohl, lub na demokratyczne i niedemokratyczne państwa prawa, a także na odmiany monarchiczne i niemonarchiczne. Skoro tak, to przymiotnik „demokratyczne” (podobnie jak „,arystokratyczne” czy „monarchiczne”) pełni w tym przypadku funkcję klasyfikacyjną i w żaden sposób nie odnosi się do cech konstytutywnych państwa prawa. Od Republiki Weimarskiej sytuacja zmieniła się zasadniczo, gdyż ład demokratyczny został uznany za jedyny polityczno-prawny kontekst dla Rechtsstaat. Jeszcze bardziej jest to widoczne w Ustawie Zasadniczej Republiki Federalnej Niemiec, która określa RFN (art. 20.1) jako demokratyczne państwo związkowe i socjalne, a nie jako demokratyczne państwo prawa. Jeśli natomiast uznamy punkty (a)-(j) jako charakteryzujące państwo prawa we współczesnym rozumieniu, to znajdziemy na tej liście podstawowe principia ustroju demokratycznego. Inaczej mówiąc, powszechnie przyjmuje się, że liberalna (w sensie politycznym, a nie ekonomicznym) demokracja jest optymalną ramą dla Rechtsstaat. Nadto, jak łatwo zauważyć, niemiecka koncepcja państwa pra- 
wa po II wojnie światowej przyjmuje austriacki model relacji pomiędzy prawami indywidualnymi, wolnością i równością a prawem pozytywnym.

Od strony semantycznej rzecz przedstawia się następująco. Użycie nazwy „demokratyczne państwo prawa” jako wyrażającej jakąś istotną kwalifikację stosowaną w odniesieniu do Rechtsstaat logicznie pociaga (każdy rodzaj może być dychotomicznie podzielony na dwa wzajemnie wykluczające się gatunki) możność zaistnienia niedemokratycznego państwa prawa bądź demokratycznego państwa bezprawia, a oba te przypuszczenia wyglądają na wewnętrznie sprzeczne, przynajmniej w świetle obecnej doktryny polityczno-prawnej. Jeśli przypuszczenie to jest trafne, termin ,demokratyczne państwo prawa” jest pleonastyczny w tym sensie, że jego pierwszy składnik jest redundantny. Inaczej mówiąc, przymiotnik ,demokratyczne” nic nie dodaje do znaczenia kontekstu „państwo prawa”. W terminologii dobrze znanej logikom i językoznawcom, przymiotnik ,demokratyczne” nie pełni w zwrocie „demokratyczne państwo prawa" roli determinatora, tj. nie wydziela gatunku z rodzaju. W konsekwencji, kwalifikacja państwa prawa jako niedemokratycznego zmieniałaby znaczenia terminu ,państwo prawa” na jego przeciwieństwo, podobnie jak fałszywy przyjaciel nie jest przyjacielem, ale wrogiem. „Niedemokratyczny” i „fałszywy" funkcjonują w rozważanych kontekstach jako tzw. modyfikatory, tj. określniki zmieniające ustalony sens rzeczowników (także terminów złożonych), z którymi współwystępuja. Nie jest wykluczone, że nazwa „demokratyczne państwo prawa" pełni funkcje retoryczne z uwagi na silnie wartościujący sens jej pierwszego członu, ale to nie usprawiedliwia posługiwania się nią tam, gdzie precyzja jest nader wskazana.

Na początku wspomniałem, że koncepcja państwa prawa powstała w Niemczech, a dalej starałem się pokazać, że pozostawała i zmieniała się w ścisłym związku z prądami myślowymi i potrzebami politycznymi tego kraju. Powstaje kwestia, zaznaczona już zresztą na początku niniejszego artykułu, związku idei Rechtsstaat z praworządnością. Przyjmijmy, że praworządność to tyle, co rządzenie za pomocą prawa. Odróżnia się przy tym praworządność formalną i praworządność materialną. Pierwsza polega na tym, że państwo jest rządzone przez prawo bez względu na jego treść, a druga, że aby mówić o praworządnym państwie, prawo, które jest stosowane w rządzeniu, winno spełniać pewne określone kryteria aksjologiczne. Jeśli bierze się praworządność w sensie formalnym, każde państwo jest praworządne, ponieważ każde stosuje jakieś prawo. Być może są jakieś przypadki szczególne, np. stan wyjątkowej anarchii, w którym prawo nie działa, ale każde w miarę sprawnie funkcjonujące państwo jest praworządne. Inaczej ma się sprawa z praworządnością materialną. Przypuśćmy, że punkty (a)-(j) definiują aksjologię materialnej praworządności. Wówczas są państwa praworządne, spełniające przyjęte warunki aksjologiczne, i państwa niepraworządne, które tych wymagań nie spełniają. Analogia z państwem prawa jest wyraźna. Normalne użycie terminu „państwo pra- 
worządne" jest pleonastyczne w przypadku praworządności formalnej i substancjalne (istotne), gdy aplikujemy praworządność materialną. Z drugiej strony, tak jak postulat rządzenia za pomocą prawa jest jednym $\mathrm{z}$ elementów modelu państwa prawa, tak też praworządność materialna zakłada formalną. $\mathrm{Z}$ drugiej jednak strony, jeśli model francuski relacji pomiędzy prawem pozytywnym, wolnością i równością oraz prawami indywidualnymi zostaje przyjęty, kodeksy muszą spełniać warunki praworządności materialnej. Dalsza analogia polega na tym, że wobec praworządności materialnej powstają podobne pytania jak wobec państwa prawa, np. jaki stopień odstępstwa od założonego ideału aksjologicznego wystarcza do uznania danego państwa za niepraworządne lub, odwrotnie, jaki stopień spełniania owego ideału uprawnia do przyznania cechy praworządności. Kategoria praworządności materialnej jest ideą regulatywną w tym samym sensie jak pojęcie państwa prawa i rodzi podobne problemy. To, że w Niemczech powstała koncepcja państwa prawa, natomiast w Wielkiej Brytanii chętniej powiada się o rule of law, a we Francji mówi się principe de légalité, wynika z odmiennych tradycji filozoficznych, politycznych i prawnych. W szczególności, stopień liberalizmu w tych państwach bywał od XVIII w. z reguły większy niż w Niemczech, ale różnice te zostały zniwelowane po II wojnie światowej. Obecnie pojęcie państwa prawa zyskało dużą popularność w Unii Europejskiej i stało się normą ustrojową, na której straży mają stać już nie tylko instytucje wewnętrzne, ale także międzynarodowe, zwłaszcza trybunały praw człowieka. Niemniej jednak jest w zasadzie bez znaczenia, czy powiemy o państwie prawa czy państwie praworządnym (w sensie materialnym).

\section{THE STATE OF LAW. REMARKS OF A PHILOSOPHER}

\section{Sum mary}

The concept of the state of law is not only of historical importance, but it also plays a significant role in the contemporary political and legal though. In particular, it has become one of the elements of the legal order that prevail in the European Union member States. The concept of the state of law originated in the German legal doctrine in the first quarter of the 19th century. It drew from the Kant's idea of a reason-guided society. The fullest definition of the idea of the state of law was probably explained by Robert von Mohl in his work "Encyclopaedia of Political Sciences" published in 1859. The ideas it contained, however, had been known already in the thirties of that century. According to Mohl, the state of law is not a form of state, but rather a certain order of rights and duties of the state towards its citizens as well as the citizens towards the state. Hence it does not matter whether a state is a monarchy or a republic. There are 
many controversies when it comes to the history of the state of law. Among the main ones is the question whether the criteria of the state of law are of a formal or substantial character. The formal conception of the state of law prevailed in the $19^{\text {th }}$ century Germany and the Weimar Republic. Since the Second World War and the negative experience with a totalitarian state, both fascist and communist, it has been accepted that there is no state of law without a minimum, rather broader than narrower, of citizen's rights and institutions that secure them. The paper presents the origin and development of the concept of a state of law and compares it with the concept of the rule of law.

\section{DE L’ÉTAT DE DROIT : REMARQUES D’UN PHILOSOPHE}

\section{Ré s u m é}

La notion de l'État de droit a non seulement une signification historique mais elle joue, en outre, un rôle essentiel dans la pensée contemporaine politique et juridique, et notamment, elle est devenue l'un des éléments de l'ordre juridique en vigueur dans les États membres de l'Union européenne. La conception de l'État de droit apparaît dans la doctrine juridique allemande durant le premier quart du XIX ${ }^{\mathrm{e}}$ siècle. Elle se réfère à l'idée kantienne portant sur la société gouvernée par la raison, et de ce fait réalisant un ordre des choses exemplaire. Cependant, même si elle est déjà populaire dans les années 30 du XIX ${ }^{\mathrm{e}}$ siècle, la doctrine de l'État de droit est présentée de manière la plus ample dans l'œuvre de Robert von Mohl, intitulée Encyclopédie des sciences politiques, publiée en 1859. Von Mohl dit clairement dans son ouvrage que l'État de droit n'est pas une forme de l'État mais que c'est plutôt un système des droits et obligations de l'État envers ses citoyens et ceux des citoyens envers l'État. Que l'État soit une monarchie ou une république, cela reste sans importance pour la doctrine. L'histoire de la notion de l'État de droit est pleine de controverses. La plus importante porte sur les critères de l'État de droit : ont -ils un caractère formel ou matériel ? La conception formelle de l'État de droit prédomine en Allemagne du XIX ${ }^{\mathrm{e}}$ siècle ainsi qu'en République de Weimar. À l'issue de la Seconde Guerre mondiale, compte tenu de l'expérience du totalitarisme connu tant dans le régime fasciste que dans celui du communisme, une thèse est communément admise, à savoir : il n'y a pas de l'État de droit sans l'existence d'un certain nombre minimum (plutôt large que restreint) des droits civils et des institutions qui les garantissent. L'article traite donc de la naissance et de l'évolution de la conception de l'État de droit. Il la met en outre en juxtaposition avec la notion de la légalité. 